\title{
Editorial
}

\section{Biliary Atresia - Too Few, Too Many Centers?}

\author{
Jorge Amil Dias \\ Pediatra e Gastrenterologista Pediátrico, Unidade de Gastrenterologia Pediátrica, Centro Hospitalar S. João, Porto, \\ Portugal
}

\section{Keywords}

Biliary atresia - Neonatal cholestasis - Neonatal jaundice . Kasai procedure

\section{Atresia biliar - Poucos ou muitos centros?}

\section{Palavras Chave}

Atresia biliar · Colestase neonatal · Icterícia neonatal · Kasai

Extrahepatic biliary atresia (EHBA) represents one fine example of a pathological condition where timely diagnosis and skilled surgical treatment modifies the longlife prognosis.

The Kasai procedure where the biliary ducts are directly connected to a loop of intestine (creating a hepatoenteric anastomosis) allowing drainage of bile into the gut modifies the risk of chronic cholestasis and severe liver damage that otherwise leads to cirrhosis and might require liver transplantation.

The efficacy of the treatment of babies with EHBA is the end result of early diagnosis and prompt referral to surgery plus the skill and experience of the surgical team as well as postoperative care.

\begin{tabular}{ll}
\hline KARGER & $\begin{array}{l}\text { () 2017 Sociedade Portuguesa de Gastrenterologia } \\
\text { Published by S. Karger AG, Basel }\end{array}$ \\
E-Mail karger@karger.com & \\
www.karger.com/pjg & This article is licensed under the Creative Commons Attribution- \\
& NonCommercial-NoDerivatives 4.0 International License (CC BY- \\
NC-ND) (http://www.karger.com/Services/OpenAccessLicense). \\
Usage and distribution for commercial purposes as well as any dis- \\
tribution of modified material requires written permission.
\end{tabular}

Being a delicate surgical procedure, the experience of the surgeon has a central role in the treatment of these babies.

In various countries, it was felt that concentrating these rare cases in a limited number of surgical centers allowed more experience and better outcome. The percentage of children that ultimately needed liver transplantation was a good measure of that policy. Clearly that type of health policy may face some opposition from individual surgical centers as every pediatric surgeon wishes to gain experience in diverse and skillful procedures.

Different approaches were used to address ways to implement policies to concentrate experiences. In the UK, a regulation from the Department of Health determined that only 3 centers are allowed to perform the Kasai procedure in EHBA and all cases must be referred to one of these units. This concentration led to considerable improvement in results and decrease of transplants needed in babies with EHBA [1-4].

In France, there was an initiative from the professionals that determined that a limited number of centers would perform the Kasai procedure but the surgeon from the referring center would be involved in the surgical treatment. In Portugal, there has been no implemented strategy and each center is allowed to determine whether surgery will be performed locally or the baby is referred to another hospital. 
It would be unwise to link treatment efficacy to the sole experience of the surgeons. Timely identification of cholestatic infants and initial workup are of paramount importance to refer patients in the right window of opportunity for correct treatment. Correct diagnosis of EHBA and exclusion of other conditions requires skilled experienced professionals and diagnostic procedures $[5,6]$.

In the present issue of this journal, Neto et al. [7] report a single-center experience with native liver survival that matches some larger international centers. The authors deserve appraisal for their results, which is the joint outcome of diagnostic workup, surgery and follow-up. These results come from a limited annual number of cases and are insufficient to disprove other international series or recommendations. However, they should prompt the various national centers to pool their results in a national unified registry that may help to define the best strategy for the benefit of children affected by the disease. This has been done in other countries and some lines of action were proposed $[8,9]$.
Screening for pale stools is an easy procedure in which parents may be engaged, if given simple methods. In Brazil, the "yellow alert" screening card is being used for early diagnosis of pale stools [10]. The same project is being replicated in Portugal and hopefully results will be published in due course.

Altogether, EHBA is a severe disease where appropriate early diagnosis and intervention are essential for the long-term prognosis and well-being of babies affected. Given the seriousness and potential consequences of mishandling these babies requires a national strategy that should emerge from the sensible initiative of professionals or regulatory authorities. The present report from Neto et al. [7] may be a good motif for an unbiased sensible evaluation and appropriate decisions in health policies.

\section{Disclosure Statement}

The author has no conflicts of interest to declare and there was no funding source for the present work.

\section{References}

1 Butler AE, Schreiber RA, Yanchar N, Emil S, Laberge JM: The Canadian Biliary Atresia Registry: improving the care of Canadian infants with biliary atresia. Paediatr Child Health 2016;21:131-134.

2 Davenport M, Ong E, Sharif K, Alizai N, McClean P, Hadzic N, et al: Biliary atresia in England and Wales: results of centralization and new benchmark. J Pediatr Surg 2011;46: 1689-1694.

3 McKiernan PJ, Baker AJ, Lloyd C, Mieli-Vergani G, Kelly DA: British paediatric surveillance unit study of biliary atresia: outcome at 13 years. J Pediatr Gastroenterol Nutr 2009; 48:78-81.
4 Schreiber RA, Barker CC, Roberts EA, Martin SR: Biliary atresia in Canada: the effect of centre caseload experience on outcome. J Pediatr Gastroenterol Nutr 2010;51:61-65.

5 Fawaz R, Baumann U, Ekong U, Fischler B, Hadzic N, Mack CL, et al: Guideline for the evaluation of cholestatic jaundice in infants: joint recommendations of the North American Society for Pediatric Gastroenterology, Hepatology, and Nutrition and the European Society for Pediatric Gastroenterology, Hepatology, and Nutrition. J Pediatr Gastroenterol Nutr 2017;64:154-168.

6 Santos Silva E, Moreira Silva H, Azevedo Lijnzaat L, Melo C, Costa E, Martins E, et al: Clinical practices among healthcare professionals concerning neonatal jaundice and pale stools. Eur J Pediatr 2017;176:361-369.
7 Neto B, Borges-Dias M, Trindade E, EstevãoCosta J, Campos JM: Biliary atresia - clinical series. GE Port J Gastroenterol 2017, DOI: 10.1159/000480708.

8 Leonhardt J, Kuebler JF, Leute PJ, Turowski C, Becker T, Pfister ED, et al: Biliary atresia: lessons learned from the voluntary German registry. Eur J Pediatr Surg 2011;21:82-87.

9 Petersen C, Harder D, Abola Z, Alberti D, Becker T, Chardot C, et al: European biliary atresia registries: summary of a symposium. Eur J Pediatr Surg 2008;18:111-116.

10 Santos JL, Carvalho E, Bezerra JA: Advances in biliary atresia: from patient care to research. Braz J Med Biol Res 2010;43:522-527. 